\title{
Construção da “Peronização" na Argentina: da SeCretaria do Trabalho e Provisão À PResidênCla DA REPÚBLICA
}

The Construction of "Peronization" in ARgentina: from the SeCRetary of LABOUR and Provision to the PRESIDENCY OF THE REPUBLIC

Cristina Isabel Abreu Campolina de Sa* ccampolinadesa@gmail.com

RESUMO: Neste artigo, trataremos da formação da Secretaria do Trabalho e a afirmação de Perón, o secretário, como o "protetor dos trabalhadores", e subsequente "Peronização" na Argentina. A vitória de Perón junto aos trabalhadores foi um caminho traçado de maneira lenta e metódica segundo um plano estratégico preconcebido. Perón conseguiu implantar uma ordem social diferente da conhecida na Argentina graças à apresentação de um programa de aplicação da justiça social e da busca da cidadania. Os trabalhadores, com demandas a muito frustradas, se harmonizaram com o líder beneficiando-se com as novas leis trabalhistas. A década de 1930, conhecida como a "década infame", deixou um campo propício para a emergência de um líder. Perón soube usar do contexto histórico para construir sua imagem e tornar-se o salvador da pátria. 017 de outubro será a prova concreta dessa aliança. Aqui trataremos dessa trajetória.

PALAVRAS-CHAVE: Trabalhismo, Peronização, Autoritarismo.

ABSTRACT: We will discuss the formation of the Labour Secretariat and the claim of Perón, the secretary, as the "protector of the workers" and the posterior "Peronization" in Argentina. Perón's victory with the workers was a path slowly and methodically outlined according to a preconceived strategic plan. Perón was able to establish a social order different from the one known in Argentina by submitting a program of social justice and pursuit of citizenship. Workers with demands long frustrated reconciled with the leader by taking advantage of the new labor laws. The 1930s, known as the "infamous decade", left a favorable field for the emergence of a "Messianic" leader. Perón knew how to use the historical context to build his image and become the savior of the nation. The $17^{\text {th }}$ of October would be the concrete proof of this alliance. Here we will deal with this process.

KEY-WORDS: The Labor movement, "Peronization", Authoritarism.

Em geral, as explicações sobre o golpe político-militar de junho de 1943, na Argentina, têm como ponto de partida a crise ideológica e o tipo de política empreendida pelo regime conservador em um mundo de guerra. A de se ter em conta que o alinhamento das grandes potências dividiu os setores conservadores que controlavam o Estado. O dilema residia na incompatibilidade entre os interesses econômicos e culturais, por um lado, e a posição política e ideológica, por outro. Noutras palavras, enquanto o capitalismo e o liberalismo constituíam-se em um forte atrativo, o fascínio pelo fascismo era maior.

\section{Ascensão de Perón}

Imediatamente após o golpe, foram tomadas severas medidas de repressão contra os sindicatos comunistas. Esse fato, afirma Bergquist (1990, p. 198), não foi capaz de deter a

*Doutorado pela Universidade Federal de Minas Gerais (2007). Atualmente é professora adjunto da Universidade Federal de Minas Gerais, atuando na área de História da América Latina.

Hist. R., Goiânia, v. 21, n. 3, p. 88-109, set./dez. 2016 
mobilização operária e a capacidade das agremiações marxistas para "lanzar costosas y masivas huelgas". Segundo o mesmo autor, nesse cenário de luta social quase incontrolável foram formuladas as políticas trabalhistas corporativistas pela facção peronista dentro da junta militar (GOU). A urgência da implementação de uma política trabalhista para enfrentar os problemas das classes desfavorecidas já havia sido manifestada pelo general Ramírez: "Resolver nossos problemas sociais, sobre bases justas, que sejam garantia de tranquilidade e bem-estar coletivos" (LA NACIÓN, 8 out. 1943, p. 2).

A política social do governo da revolução caracterizou-se pelo rigor. Tratava-se de um paternalismo autoritário que exigia a obediência e disciplina dos trabalhadores em troca de alguns benefícios sociais. Pelo estatuto sindical de agosto de 1943 ficou patente o controle que o Estado exerceria sobre os trabalhadores. Os sindicatos só poderiam funcionar com personeria gremial e teriam suas reuniões e manifestações públicas regulamentadas e fiscalizadas pelo Estado. Em 27 de novembro de 1943, o Departamiento Nacional del Trabajo, até então uma dependência do Ministério do Interior, foi transformado pelo Decreto 156.074 em Secretaria de Trabajo y Previsión sob a titularidade do Coronel Juan Domingo Perón. Para Bergquist (1990, p. 198, tradução nossa), "Perón nunca ocultou seu temor a um movimento operário com consciência de classe; e foi muito honesto com os trabalhadores em torno da natureza corporativista de sua filosofia e o significado de seu programa".

Em documentação qualificada pela GOU como "estrictamente confidencial e secreta", Potash (1984, p. 187-188, tradução nossa) detectou em seu conteúdo um estilo de discurso que muito provavelmente tenha sido elaborado por Perón:

[...] as cidades e os campos estão povoados de lamentações que ninguém ouve. [...] o operário explorado pelo patrão, [...] A solução está precisamente na supressão do intermediário político, social e econômico. Para o qual é necessário que o Estado se converta em órgão regulador da riqueza, diretor da política e harmonizador social. [...] Isso implica na extirpação do agitador social [...].

Tudo indica que esse foi o mote usado por Perón para empreender sua trajetória política e viabilizar suas intenções pessoais: o medo do avanço comunista, que nunca ficou velado; pelo contrário, o fantasma vermelho estava em toda parte e em todas as agrupações clássicas como a Acción Argentina e a Defesa de los Pueblos Libres. Logo, "perante esse 'estado de emergência' haveria de se tomar atitudes firmes contra todo tipo de pressão" (POTASH, 1984, p. 208-209, tradução nossa). 
No dia primeiro de dezembro de 1943, Perón assumiu a Secretaria de Trabajo y Previsión, base do lançamento de toda sua estratégia política. Perón explorou um novo tipo de relação com os Grêmios de Trabalhadores, incomum no comportamento de um militar profissional que exercia uma função simplesmente burocrática. Forjou-se uma rede de comunicação com o setor sindical, com o objetivo de construir uma imagem da revolução revestida de grande sensibilidade aos problemas da classe trabalhadora. Para a concretização dessa política, foi tomada uma série de medidas legislativas criando novos benefícios sociais para a classe trabalhadora rural e urbana. Os benefícios já existentes foram estendidos a setores que ainda não tinham sido favorecidos por serem menos combativos ou menos expressivos se comparados com os trabalhadores das ferrovias, frigoríficos e têxteis. A política trabalhista, com sua natureza corporativista e controladora era, para Perón, a única forma de impedir a realização de seu temor: um movimento operário organizado e atuante.

Ao mesmo tempo em que Perón empreendia sua política através da Secretaria do Trabalho, graves conflitos ocasionados por dissensões internas entre nacionalistas-GOU e os liberais minavam o comando do governo golpista. Ramírez permaneceu na presidência durante oito meses quando, por razões políticas, entregou o cargo ao vice-presidente provisório, General Edelmiro A. Farrell. Antes, porém, rompeu as relações com o Eixo através do decreto de 26 de janeiro de $1944 .{ }^{1}$ A remoção de Ramírez (segunda depois do golpe de quatro de junho) deixou claro, para a oposição civil ao governo (liderada pela UCR), que a volta à normalidade institucional era apenas um sonho a ser acalentado. Perón destacou-se novamente assumindo a vice-presidência do país e o Ministério da Guerra, cargos que manteve concomitantemente ao da Secretaria do Trabalho.

Em discurso proferido em primeiro de dezembro de 1943, quando da posse como secretário do trabalho, Perón demonstrava notável habilidade política:

[...] o Estado Argentino tratará de intensificar o cumprimento de seu dever social. Todos os conflitos que detêm a atividade industrial ou comercial afetam profundamente a economia pública e privada, além de destruir o equilíbrio e a harmonia social tão necessários para uma evolução progressista. Nesse sentido, o Estado não pode continuar sendo um expectador irresoluto e estático... É necessário interpretar a Secretaria de

\footnotetext{
${ }^{1}$ Ramírez, conhecido como "o amigo dos coronéis", foi acusado em 1944 pelos Estados Unidos de envolvimento com o golpe político-militar liderado pelo Movimento Nacionalista Revolucionário boliviano que derrubou o governo em dezembro de 1943 e de seus esforços para obter armas da Alemanha nazista. Essas acusações foram responsáveis por sua saída do governo.
} 
Trabajo y Previsión como um organismo [...] para enfrentar a solução dos problemas criados por uma época de evolução e cultura de massas, por uma divisão equitativa dos frutos da terra e do trabalho [...] (LA NACIÓN, 2 dez. 1943, p. 3, tradução nossa).

Partindo do princípio de que o poder do Estado deveria aplicar-se mais em favor do trabalho que do capital, o novo secretário passou a desempenhar funções insólitas e desconhecidas na Argentina. Convicto da precisão do diagnóstico da situação caótica do país, proveniente da ausência de virtude pública, Perón pavimentou o caminho que o levaria à presidência da República.

Para tornar a Argentina um grande país, a primeira medida seria o saneamento político. Até 1943, com a entrada de Perón na política, a incompetência era socialmente condicionada pela imobilidade dos setores dominados e pela astúcia dos setores dominantes. Com a criação da Secretaria do Trabalho, o país deu os primeiros passos concretos em matéria de legislação social. A segunda medida seria a tomada de consciência de patrões e empregados, que ao levarem em conta a dimensão das pendências sociais, perceberiam que os problemas eram de todos. Nesse contexto, as empresas poderiam traçar previsões para o futuro desenvolvimento de suas atividades, pois teriam a garantia de que, se as retribuições e o trato que dessem a seu pessoal concordassem com as regras de uma convivência saudável, receberiam da parte do Estado o apoio necessário para a melhoria da economia em geral, e por consequência, o engrandecimento do país. Os operários teriam a garantia de que as normas do trabalho estabelecidas nos direitos e deveres de cada um seriam exigidas pelas autoridades do trabalho com o maior cuidado, sendo explicitadas severas sanções ao não cumprimento das mesmas (PERÓN, 1944). A terceira medida seria a erradicação do "vírus" causador da enfermidade das massas operárias, as ideologias estranhas: o comunismo e o socialismo (PERÓN, 1944). Equacionadas essas pendências, o esforço conjunto da sociedade pela paz social e pelo progresso do país levaria todos os argentinos a uma única categoria - a dos que se esforçam pela regeneração da Pátria. Sobre esses pilares a dominação autoritária foi tomando forma.

Entre os anos de 1943 e 1946 foram editados 111 decretos e leis, enquanto apenas sete foram editados entre 1940 e 1943. Perón aproximava-se cada vez mais dos sindicatos organizados, nos quais procurava apoio para o desenvolvimento de sua política trabalhista. A Secretaria do Trabajo y Provisión tinha status ministerial, com a prerrogativa de interferir em 
todas as secretarias e departamentos provinciais que estivessem relacionados com assuntos trabalhistas de ordem regional. A centralização de poder permitiu que Perón dirigisse o processo de controle da classe operária, sem precedentes na história do país.

De acordo com o artigo 12 do Decreto 156.074 ficou estabelecido que todos os departamentos de trabalho, divisões ou escritórios nas Províncias passariam a ser escritórios regionais da Secretaria do Trabalho e Bem-estar. Foi criado o Tribunal do Trabalho, em 1944, através do Decreto 32.347, no qual o Estado, como instância superior, tinha autoridade nas disputas e conflitos trabalhistas. ${ }^{2}$

O poder de intervenção da Secretaria foi base angular que deu sustentação à relação entre Perón e os sindicatos. Resultaria daí o desenvolvimento de uma política particular do secretário, independente do governo do presidente Ramírez. Sob o lema da "harmonia e proteção", Perón controlou politicamente a classe operária através dos órgãos estatais. No 1으 de maio de 1944, em discurso à Nação, Perón afirmava:

[...] estamos buscando a unidade de todos os Argentinos [...] de modo que o capital, em harmonia com o trabalho possam formar a base de nosso engrandecimento industrial e bem-estar coletivo. [...] 0 exército não abandonou seus quartéis movido por um sentimento de ambição. Foi o clamor da rua, da oficina, e do campo que chegou até ele, para golpear a suas portas em demanda de justiça [...] (PERÓN, 1944, p. 4, tradução nossa).

Nesse momento ganha pleno sentido o sindicalismo como base de apoio ao governo (catalisador das tensões sociais) e à legislação social. Era necessário não só controlar a classe operária como também garantir seu apoio ao bloco de poder que se constituía.

A base política de Perón, no plano sindical, concentrou-se fundamentalmente nas organizações que constituíam a CGT1 e a USA. As atividades da CGT2, formada principalmente por socialistas, foram proibidas por decreto em julho de 1943, enquanto a CGT1 recebia inúmeras vantagens. ${ }^{3}$ Os setores sindicais mais politizados que não se mostraram dispostos a colaborar com a Secretaria do novo governo tiveram seus sindicatos fechados e colocados sob a intervenção do Estado. Foram criadas várias associações tendo em vista o esvaziamento daquelas que se opunham a Perón, enquanto a CGT1 tornava-se para o secretário um

\footnotetext{
${ }^{2}$ Ver Zamor (1968).

${ }^{3}$ A CGT2 foi extinta por ser considerada de esquerda. (LA NACIÓN, 14 jun. 1943, p. 3). 
instrumento de importância vital na viabilização, a partir do aparelho de Estado, do controle e cooptação dos demais sindicatos.

A política social do governo foi violentamente criticada por entidades patronais integrantes da Câmara do Comércio e da União Industrial traduzida no "Manifesto das Forças Vivas". ${ }^{4}$ Aos protestos das associações patronais à política social oficial, seguia-se o questionamento da legalidade das medidas de reforma na legislação trabalhista. O texto, que foi publicado no jornal La Nación de 12 de junho de 1945, atesta a apreensão das classes proprietárias perante o ambiente de agitação social que danificava a disciplina e o esforço produtivo da coletividade.

[...] o clima de descontentamento que se origina é instigado desde as esferas oficiais. Longe estamos de negar a existência de um genuíno problema social, de caráter permanente e universal, cuja solução só pode chegar através da honesta colaboração das partes e sob a serena supervisão do Estado. Nossa oposição é contra a criação de um clima de suspeita, provocação e rebeldia que estimula ressentimento e gera reclamações permanentes. [...] Desde a criação da Secretaria do Trabalho este espírito e o sentido unilateral das decisões, justificadas pela necessidade de extirpar o comunismo, têm interferido na resolução dos problemas sociais. Esta situação é ainda mais lamentável quando se considera que é o produto de uma vontade pessoal, que é sempre transitória [...] (LA NACIÓN, 12 jun. 1945, p. 2, tradução nossa).

A elite agrária, através de La Sociedad Rural, também se pronunciou contra a promulgação do chamado Estatuto del Peón. Os fundamentos da ordem existentes, segundo a Sociedade Rural, eram ameaçados pelas reformas realizadas pelo Secretário do Trabalho (Perón). A nova legislação, de acordo com um porta-voz da Sociedade Rural, "haverá de semear o germe da desordem social, ao inculcar em pessoas de cultura limitada aspirações irrealizáveis e colocar o jornaleiro acima do patrão em comodidades e remuneração" (TORRE, 1988, p. 124, tradução nossa).

Assim, ficava claramente definida a insatisfação e a ruptura das classes patronais com o governo. Para Waisman (1987, p. 175, tradução nossa),

[...] o plano de Perón acarretava mais do que a "socialização" de uma fração da produção previamente apropriada pelas classes agrárias e industriais mais altas. Também envolvia uma redistribuição mais permanente do poder político. As elites econômicas foram obrigadas a contribuir para a institucionalização deste estado independente, o qual viam mais como um

\footnotetext{
${ }^{4}$ O Manifesto foi elaborado pela Bolsa de Comércio, Câmara Argentina de Comércio, Confederação Argentina de Comércio, Indústria e Produção, Bolsa de Cereais, Câmara de Grandes Feiras e Anexos e Câmara de Exportadores.
} 
instrumento de um indivíduo, Perón, do que como um mecanismo neutro que regularia o conflito social [...].

A burguesia industrial e a oligarquia mostravam o desagrado com a política de Perón por estarem convictos de que a aplicação das leis trabalhistas incidiria negativamente na acumulação de capitais. Mas a essa altura qualquer outro projeto de dominação que previsse a exclusão de Perón no poder, tornava-se fadado ao fracasso, dada à influência que ele exercia sobre o General Farrell, que substituiu o presidente Ramírez, e pelo encaminhamento irrevogável da política trabalhista.

Perón declarava sua posição em relação à classe dominante através da rádio oficial, na busca do apoio popular em nome da defesa da Revolução de Junho. Em 20 de julho de 1945 foi publicado no jornal La Prensa um discurso no qual Perón anunciou o nascimento de um novo mundo pela "afirmação dos direitos, das responsabilidades e da intervenção das massas operárias na solução dos problemas fundamentais. [...] A Secretaria do Trabalho seria, no caso, a fonte da passagem da dominação da burguesia à dominação das massas" (LA PRENSA, 20 jul. 1945, p. 2, tradução nossa). Apesar do tom radical do discurso, vale lembrar que essa fala, apesar de impactante, está longe de conter um significado político revolucionário. Perón movia-se num espaço paradoxal onde necessitava, simultaneamente, enfatizar a política trabalhista e indispor o mínimo com os patrões.

A reação dos sindicalistas ao Manifesto foi imediata, culminando no grande comício de 12 de julho de 1945, com a participação da CGT1, cuja chamada era: “Em defesa das melhorias obtidas por intermédio da Secretaria do Trabalho e Previdência". Em 24 de junho de 1945, a manchete de La Prensa anunciava à Nação:

[...] os trabalhadores fazem escutar sua voz. Afirmava o periódico: A propósito de recentes declarações de entidades patronais, que tem criado incerteza e mal-estar nas classes trabalhadoras, os grêmios que subscrevem a presente, reunidos espontaneamente, nessa oportunidade resolveram reafirmar e fazer públicas outras adesões formuladas à "obra humana" e definitiva de política social, iniciada e levada à prática pela Secretaria de Trabajo y Provisión [...] (LA PRENSA, 1945, p. 1, tradução nossa).

Candido Gregorio, integrante do Consejo Directivo de la Unión Obrera Têxtil, enfatizou o sentido e conteúdo da manifestação afirmando:

[...] a classe trabalhadora e os trabalhadores têxteis não podem permanecer indiferentes ante à situação criada, por entender que nesta emergência o aparente ataque à Secretaria de Trabajo y Previsión e suas atuais autoridades reflexas nas "Forças Vivas" demonstram o desejo de manter um estado de 
coisas com o conceito arbitrário que sempre tem sustentado as mesmas [...] (LA PRENSA, 26 jun. 1945, p. 4, tradução nossa).

O Ato Público, de 12 de julho de 1945, foi uma prova do vigor dos trabalhadores na luta pelos direitos sociais. O Ato refletiu o estado de espírito dos trabalhadores, através de uma operação que pretendia exorcizar os demônios dos governos anteriores e da reacionária classe patronal. O orador que mereceu maior destaque foi Angel Borlenghi, representante dos empregados do comércio e secretário da Comisión de Unidade Sindical. Na defesa do sindicalismo, Borlenghi criticou a reação capitalista e defendeu veementemente a manutenção dos direitos já conquistados pelos trabalhadores. Quanto à questão da participação política, Borlenghi declarou:

[...] não estamos conformados que se fale em nosso nome, vamos falar por nós mesmos. E temos claro que o movimento sindical argentino, colocandose à altura dos mais adiantados do mundo, gravita na solução dos problemas políticos, econômicos e constitucionais da república e com absoluta independência [...] (LA PRENSA, 12 jul. 1945, p. 4, tradução nossa).

Segundo Pont (1984, p. 34, tradução nossa),

[...] o conteúdo do discurso tinha um sentido mais político que sindical, mas ali estavam as evidências de como o movimento operário entendia a relação entre política e sindicatos que havia começado a ter relevância a partir de 1940, aproximadamente, adquirindo real gravitação quando as condições políticas, econômicas e gremiais se fizeram favoráveis a partir de 1943. Desse modo, a autonomia política converteu-se em uma reivindicação importante para o movimento operário organizado e no instrumento mais efetivo para fortalecer e manter a autonomia sindical [...].

Foi a partir do manifesto das "Forças Vivas" que a classe operária organizada pôde compreender a necessidade de criar um porta-voz político que garantisse, em nível nacional, a defesa de seus interesses de classe (PONT, 1984, p. 37, tradução nossa). A ideia da ação política do movimento sindical surgiu, nesse momento, da necessidade histórica da classe operária argentina. Mediante a política social desenvolvida pela Secretaria de Trabalho e Previsão, um novo comportamento foi adotado pela classe operária com o objetivo de preservar os benefícios conquistados. ${ }^{5}$

O direito de exercer atividades políticas foi obtido pelos sindicatos através do Decreto 23.582 sancionado em 2 de outubro de 1945. O decreto, que funcionou como um

\footnotetext{
${ }^{5}$ Segundo Foucault (2000), “o poder está localizado no aparelho de Estado e nada mudará na sociedade se os mecanismos de poder que funcionam fora, abaixo, ao lado dos aparelhos de Estado no nível muito mais elementar, quotidiano, não forem modificados" (p. 149-150). Ver, também, Foucault (1999).
} 
amortecedor dos conflitos sociais, impôs os limites desse direito, definidos pela fidelidade à moral, às leis, à ordem social e às instituições fundamentais da nação. Esses dispositivos, de cunho autoritário, possibilitaram ao Estado impedir a formação de um sindicalismo autônomo e independente. Com efeito, as organizações sindicais poderiam ser livremente constituídas, mas não sobreviveriam no caso de qualquer transgressão à concessão de privilégios patrocinados pelo Estado.

\section{Perón e o 17 de Outubro de 1945}

Em 9 de outubro de 1945, Perón foi deposto dos cargos públicos que ocupava por um grupo de oficiais que se opunha a sua crescente influência no regime militar, para retornar, triunfalmente, no dia 17 de outubro, em consequência de grande mobilização popular levada a efeito pelos líderes sindicais. Se a jornada de 9 de outubro, quando alijado do poder e levado à ilha Martin Garcia, significou a vitória dos setores "civis" ou anti-Peronistas, o 17 de outubro significou a vitória de Perón e a força que o contingente operário assumia no campo político. A ampla ressonância do 17 de outubro na Argentina foi um desdobramento das posições assumidas pelos trabalhadores em resposta ao "Manifesto das Forças Vivas" de 12 de junho de 1945. A par disso, a classe operária reforçava e conferia legitimidade a um pacto cada vez mais explícito com Perón.

Para os sindicalistas, o caminho de retrocesso na política trabalhista era inconcebível. Em 1945, eles reconheciam os benefícios sociais promovidos pela Secretaria do Trabalho e se mostravam dispostos a aceitar a assistência do Estado, qualquer que fosse sua origem para obter resultados positivos em suas reivindicações (TORRE, 1988, p. 34-35).

De acordo com Torre (1988, p. 34-35), a questão da posição apolítica defendida pelas organizações operárias modificou-se depois da Revolução de Junho de 1943. Em que pese o distanciamento para a consolidação de sistema democrático formal e o caráter fascistizante do novo regime militar, esse se mostrava mais aberto à questão social que os governos que o precederam, tanto antes como depois da revolução de 1930. Assim, afirma o autor:

[...] a inovação importante consiste em que, ao apelar a dita tradição (de precendência política), os dirigentes sindicais não se propõem a abandonar o terreno dos enfrentamentos, mas a buscar um lugar autônomo em meio a crescente polarização política [...] (TORRE, 1988, p. 34-35, tradução nossa).

Entre julho e outubro de 1945, as organizações operárias estiveram ausentes das "ruas", dificultando a possibilidade de se tornarem uma terceira força entre a elite militar e 
os setores de oposição. Apoiar abertamente Perón implicava identificar-se definitivamente com o mesmo regime militar. Todo esse período foi marcado por uma intranquilidade e insegurança que implicou em uma certa precaução natural dos trabalhadores. As mudanças ocorriam em ritmo acelerado e, ainda que favoráveis às classes desassistidas, o projeto político de Perón ainda era uma incógnita para eles. A preocupação dos dirigentes sindicais, frente à força que adquiria a ofensiva opositora, deixava-Ihes como única alternativa pender para o lado ganhador. Pelo menos naquele momento Perón era esse lado. Entende-se que o apoio a Perón foi mais que uma escolha ou contingência, foi um cálculo político.

Frente a essa posição, os socialistas foram críticos ferrenhos da CGT, acusando-a de colaboracionista e estimulando seus filiados a rechaçarem as reformas promulgadas pela Secretaria do Trabalho por considerá-las anticonstitucionais. A ordem era o desligamento em massa dos trabalhadores da central operária (CGT), cunhada com o espírito da política de direita.

Curiosamente, os comunistas, severamente perseguidos por Perón, declinaram de uma atitude radical e assumiram outra, parcialmente colaboracionista, uma vez que constatavam os ganhos sociais alcançados pelos trabalhadores. Debaixo de rigorosas acusações dos socialistas e de sindicatos como La Fraternidad, La Unión Obrera Textil e o Sindicato dos Calçados que se retiraram da CGT, o PC se defendia, reiterando a função histórica que cumpria como o legítimo defensor dos interesses da classe trabalhadora.

O jornal comunista La Orientación, publicou em 1946 a discussão de Rubens Iscaro sobre a posição do Partido Comunista em relação à importância da "unidade do movimento operário argentino, e a necessidade de sua materialização a curto prazo em torno de uma central operária única: a CGT" (1946, p. 7). Afirmava Iscaro que:

[...] apoiamos a dissolução dos velhos sindicatos de gloriosa tradição para facilitar sua unidade com organizações paralelas: por isso propomos, sem deixar de assinalar ausência do espírito democrático de alguns dirigentes, a necessidade de concretizar em torno da CGT a unidade do movimento operário argentino [...] (1946, p. 7, tradução nossa).

Respondeu também aos socialistas:

[...] Frente a essa política clara e realista que consulta os interesses mais apreciados da classe operária e do povo, que são os interesses do país, contrasta a atitude e as declarações da comissão socialista de coordenação gremial quando qualifica de 'manobras comunistas' nossa política sindical. [...] Nem antes, nem depois de 24 de fevereiro [eleição de Perón] militantes 
socialistas que dirigiam organizações sindicais contribuíram em algo para consolidar ou favorecer a unidade da classe trabalhadora [...] (ISCARO, 1946, p. 7, tradução nossa).

Dentro desse quadro, a verdadeira disputa era pela marca trabalhista; por ela brigavam comunistas, socialistas e Perón, o único líder nacional sem nenhum adversário que diluísse seu poder. Nem mesmo os apelos dos tradicionais partidos de esquerda alteravam a centralidade da figura e do poder carismático de Perón. ${ }^{6}$

Ciente da resistência patronal à política trabalhista e sendo ele, Perón, o fundador do trabalhismo e criador da legislação trabalhista, o manifesto das "Forças Vivas" podia representar um entrave de ordem operacional imprevisível. Percorrendo o caminho contrário, ao invés de pressionar os sindicatos a tomar uma posição a seu favor, Perón estrategicamente redobrou as concessões trabalhistas, enfrentando o desagrado da classe patronal. O Decreto 23.842 de 1945, sobre as Associações Profissionais, que se constituía em um novo estatuto sindical e incorporava as várias demandas dos dirigentes dos trabalhadores, foi uma das medidas adotadas para dar prosseguimento a sua missão de por ordem na desordem social.

A queda de Perón em 9 de outubro e sua gloriosa volta no 17 de outubro têm dois sentidos: um para Perón e outro para a classe operária. Para Perón, o terreno para a futura eleição à presidência da República estava pavimentado. No discurso pronunciado pelo então chefe do Poder Executivo, General Farrell, no dia 17, para a multidão de trabalhadores presentes na Praça de Maio, não faltaram palavras para referendar o poder de Perón e reconhecer sua importância para a classe trabalhadora. Declarou o Presidente:

[...] trabalhadores: vos falo outra vez com a profunda emoção que pode sentir o presidente da Nação ante uma multidão como esta que está congregada hoje na praça. Outra vez está junto a vocês o homem que, com sua dedicação e empenho, tem sabido ganhar o coração de todos: o coronel Perón. De acordo com o pedido que me foi feito, quero comunicar que o gabinete atual renunciou. O senhor Tenente Coronel Mercante será designado Secretário do Trabalho e Previsão. Atenção senhores: de acordo com a vontade dos senhores o governo não será entregue à Suprema Corte de Justiça Nacional. Estão sendo estudadas e consideradas, nas formas mais contrapostas possíveis para os trabalhadores, as últimas petições apresentadas. O governo necessita tranquilidade. Para isso lhes pede trabalho, dedicação, que estejam unidos, mas sempre respeitando aos demais, porque assim como hoje, serão mais dignos que qualquer outro grupo cidadão. Finalmente, desejo que cada um tenha sua convicção de que, com a união e o trabalho, havemos de chegar a obter a mais completa vitória

\footnotetext{
${ }^{6}$ Sobre partido e carisma, ver Panebianco (1988).
} 
da classe humilde que são os trabalhadores. Nada mais [...] (LA PRENSA, 18 out. 1945, p. 7, tradução nossa).

Em seguida, sob grande aclamação do público falou o ex-vice-presidente Coronel

Perón:

[...] trabalhadores: faz quase dois anos que destes mesmos balcões disse que tinha três honras em minha vida: a de ser soldado, a de ser patriota e a de ser o primeiro trabalhador argentino [...]. Este é o povo sofrido que representa a dor da terra mãe, que temos de reivindicar. É o povo que é a pátria. [...] Desde hoje sentirei um verdadeiro orgulho de ser argentino, porque interpreto este movimento coletivo como o renascimento de uma consciência dos trabalhadores, que é o único que pode fazer grande e imortal a pátria. [...] Há dois anos que pedi confiança. Muitos me disseram que esse povo a que eu sacrifiquei minhas honras de dia e noite iria me trair. Que saibam hoje os indignos farsantes que este povo não engana a quem os ajuda. [...] Que seja essa unidade indestrutível e infinita, porque nosso povo não somente forma essa unidade como também sabe diferentemente defendê-la [...] (LA PRENSA, 18 out. 1945, p. 7, tradução nossa).

Com efeito, o 17 de outubro conferiu aos trabalhadores o status social que almejavam, daí a percepção da necessidade de unir-se e constituir uma força política nacional em nome dos interesses da classe. ${ }^{7}$ Com o 17 de outubro marcado por um alto grau de espontaneidade e uma certa independência com relação à CGT, cresceu entre os trabalhadores o sentimento de identificação nacional, reforçando o poder de Perón que, a partir de então, passou a ter o controle sobre os militares. Para esses, à alternativa da eclosão de uma guerra civil, preferiram trazer Perón de volta ao poder. ${ }^{8}$

\footnotetext{
${ }^{7}$ As manifestações dos trabalhadores no 17 de outubro se anteciparam à data prevista pela CGT. No dia 18 de outubro de 1945, a CGT declarou à imprensa a seguinte nota: “O Comité Central da CGT que se encontrava reunido em sessão permanente há vários dias resolveu ontem declarar greve geral dos trabalhadores de todo país por 24 horas, 'paro' que se cumprirá na data com o propósito de exteriorizar o pensamento da classe operária sobre o momento excepcional que vive a Nação". (LA PRENSA, 18 out. 1945, p. 8, tradução nossa). Segue extensa lista de reivindicações.

${ }^{8}$ No mesmo dia 17 de outubro, o jornal antiperonista Critica denunciava as manobras peronistas na propaganda da greve geral chamada pela CGT para o dia 18 do mesmo mês. O jornal informava sobre os "comunicados de numerosas organizações operárias autênticas que desautorizavam a greve nazi-fascista". Ver Editorial (CRÍTICA, 17 out. 1945, tradução nossa). O jornal La Acción de San Juan, em 18 de outubro de 45 publicou uma nota informando sobre as manifestações ocorridas no dia anterior em Buenos Aires. Ao lado da coluna que descrevia detalhes da concentração em frente à Casa Rosada de pessoas que exigiam a liberdade de Perón, a Unión Obrera local deu a conhecer em comunicado que elementos nazistas da Secretaria de Trabalho e Previsão e outros valentões apoiados pela polícia haviam tratado de realizar a paralisação de todas as atividades do país em apoio ao Coronel Perón. Alertava o povo argentino e os trabalhadores do país para que estivessem conscientes perante este movimento nazi-fascista. A Unión Obrera local fez uma chamada a todos os operários para que se mantivessem à parte deste intento do nazi-fascismo, que pretendia assegurar-se na Argentina perante a derrota mundial sofrida. No dia 19 de outubro, La Acción informava que a greve do dia anterior para comemorar o "dia de glória" de Perón foi motivo de enérgica censura por parte da população sanjuanina. Comunicava, também, que a comissão diretora do Sindicato Operário da Construção considerava "que a greve decretada por elementos colaboracionistas do movimento sindical em convivência com a Secretaria de Trabalho e Provisão nada tinha que
} 
Há um dado importante no 17 de outubro que precisa ser destacado. Embora não possa ser negado o papel da CGT no movimento, esse saiu do controle da central operária, que havia marcado o paro para o dia 18. Entretanto, as respostas às demandas da CGT foram atendidas anteriormente à data prevista para a manifestação.

Segundo Sigal e Verón (1986, p. 117-118, tradução nossa):

[...] 017 de outubro foi uma data chave para o peronismo porque selou definitivamente a relação Perón/povo, ou seja, o Messias e o povo eleito. Os trabalhadores adquiriram naquele momento uma nova identidade como povo e mais, povo peronista; a operação pela qual se constituiu esse novo ator social e político foi simultânea com a prova de que o povo havia eleito Perón [...].

Nesse mesmo dia Perón abriu mão de sua condição de soldado a serviço da Pátria e assumiu definitivamente o lugar de líder dos trabalhadores: el primer trabajador. Para Sigal e Verón (1986, p. 117-118), foram grandes os efeitos do movimento do 17 de outubro. Perón passou a encarnar a expressão do povo, estabelecendo a unidade entre Pátria e povo, representado em sua própria pessoa, através do sacrifício das mais altas honras militares. Com base na comunhão do sacrifício de Perón e do povo, o pacto se tornaria indissolúvel. 017 de outubro foi designado como o Dia da Lealdade: a lealdade dos trabalhadores ao líder que, em contrapartida cumpriria suas promessas ("Perón cumple").

Plotkin (1995, p. 172) analisou o processo pelo qual o 17 de outubro foi redefinido pelo próprio regime e passou a formar parte do imaginário político peronista, representando um recurso imbatível da propaganda oficial, para reafirmar a imagem de Perón como líder carismático. O autor chama a atenção para um aspecto crucial do carisma que não foi

ver com os interesses da classe trabalhadora". O mesmo comunicado conclamava o povo a não se deixar enganar por esta "tosca manobra do nazismo criollo", ver Editorial (LA ACCIÓN, San Juan, 19 out. 1945). O The Buenos Aires Herald, em pequena nota comunicou que: "Houve algumas estimativas muito exageradas sobre o número de homens e mulheres que desfilaram ontem e anteontem. Um radialista mencionou 500.000 almas na Praça de Maio. Seria pouco possível que aquela praça suportasse mais do que 100.000 [...] Não há dúvida sobre o caráter trabalhista das massas ontem [...] Apesar das declarações dos líderes do Partido Socialista e de sindicatos trabalhistas mais antigos, pode-se admitir que o Coronel Perón tem uma seção muito importante dos trabalhadores definidamente sob seu domínio. A porcentagem real de pessoas só será dada mediante eleições honestas e justas", ver Editorial (THE BUENOS AIRES HERALD, 19 out. 1945). Contraditoriamente o jornal católico El Pueblo comentou o significado do movimento do dia anterior, "em primeiro lugar há de se destacar que esta reunião estava composta em quase sua totalidade por autênticos trabalhadores [...] Não é difícil advertir as razões que mobilizaram a tão numerosa fração do povo. As manifestações exteriorizavam uma delas, ao pedir a liberdade do ex-funcionário aludido e seu desejo de certificar-se dela. É indubitável que sua renúncia, por outra parte, havia provocado temores no sentido de que, desaparecido o gestor das melhores resoluções sociais nos últimos anos, também se atenuariam esses benefícios ou ficaria incompleta a obra iniciada por aquele à frente da Secretaria de Trabalho e Provisão", ver Editorial (EL PUEBLO, 18 out. 1945, tradução nossa). 
abordado no clássico trabalho de Weber sobre o tema. Trata-se do fato de que o carisma pode ser gerado por meio de propaganda e símbolos políticos. Usando Clifford Geertz como referência teórica, Plotkin (1995, p. 177) demonstra como a exploração sobre a manipulação de símbolos e rituais políticos durante o regime de Perón indica a possibilidade de uma investigação mais ampla sobre a natureza do carisma e do poder de Perón. A criação da imagem de que seu regime se baseava em um amplo consenso (consenso de que o autor discorda) foi possível pela obtenção gradual de um monopólio por parte do Estado do espaço público por meio da criação de um imaginário político, pautado em uma simbologia política que pontilhava todos os aspectos da vida pública e excluía, por conseguinte, outros sistemas simbólicos alternativos.

O 17 de outubro foi um acontecimento com repercussão em todos os setores da sociedade argentina e nas vicissitudes políticas dessa conjuntura histórica específica. A data é emblemática, como a marca das transformações que a sociedade argentina vinha processando em todos os seus aspectos.

Embora a década de 1930 seja um retrocesso na marcha pela democracia, foi nessa década que a industrialização, que vinha crescendo desde os anos 1920, ganhou um novo impulso e propiciou o crescimento urbano e o crescimento dos setores assalariados. Nessa conjuntura, ainda que permeada pela crise política, o movimento operário adquiriu a visibilidade que vinha ensaiando desde o final do século XIX. Assim, a questão social passou a ocupar um lugar definitivo na agenda política, impondo uma maior transparência nas posições assumida pelos governantes. A par disso incorporou-se um maior grau de representatividade na arena política, a fim de tornar governável a sociedade, impedindo a eclosão de uma revolução. ${ }^{9}$

Torre (1995, p. 19) afirma que Perón não sobreviveria ao 9 de outubro, quando foi destituído do poder, se a oposição tivesse lideranças de expressão política no país. Para o

\footnotetext{
${ }^{9}$ Arendt (1988, p. 49-50) afirma que o “jovem Marx convenceu-se de que a razão pela qual a Revolução Francesa falhara em instituir a liberdade foi porque fracassou em resolver a questão social. [...] Se Marx ajudou a libertação dos pobres, não foi por thes dizer que eles eram a encarnação viva de alguma necessidade histórica, mas por persuadi-los de que a própria pobreza é um fenômeno político, e não material, uma conseqüência mais da violência e da violação do que da escassez. Pois se a condição de miséria - que, por definição, nunca pode produzir gente de espírito livre, porque é a condição de sujeição à necessidade - era para gerar resoluções, ao invés de levá-las a ruína, seria necessário traduzir condições econômicas em fatores políticos, e explicá-las em termos políticos."
} 
autor, ao resgatar Perón do ostracismo político, a mobilização dos trabalhadores depositou em suas mãos uma oportunidade para concorrer à presidência em 1946. A vitória da coalizão peronista deixou um "legado perdurável na história argentina", uma vez que a candidatura de Perón foi o resultado do apoio das massas, apesar delas terem sido organizadas no "sistema de corporativismo sindical que neutralizou a influência da esquerda no movimento operário". Finalmente, conclui o autor,

[...] em efeito, graças ao triunfo de sua liderança popular, o Estado sobre o qual governará Perón a partir de 1946, ficará exposto à ação dos trabalhadores organizados e se converterá em mais um instrumento de sua participação social e política. O conjunto de direitos e garantias ao trabalho incorporado às instituições, à penetração do sindicalismo na estrutura estatal, e sua posição chave na sustentação do regime, terão o efeito de introduzir limites certos a sua política, particularmente no terreno econômico, e visíveis sobretudo ao diluir-se a prosperidade dos três primeiros anos entre 1946 e 1948 [...] (TORRE, 1995, p. 19, tradução nossa).

Assim, o componente popular no peronismo impôs a Perón a revalidação de sua liderança através de uma renegociação constante de sua autoridade sobre as massas operárias. As comemorações do 17 de outubro nos anos posteriores se constituíram na memória utilizada para recriar as condições de origem do regime (TORRE, 1995, p. 20-21).

Em 23 de novembro de 1945, foi criado o Partido Laborista que, segundo Cipriano Reyes (1987), um de seus organizadores, foi uma derivação do 17 de outubro de 1945. Naquele momento, ficou claro para as lideranças sindicais que o triunfo não estaria assegurado se não fossem consolidadas as conquistas sociais obtidas através de um movimento operário eficaz ante a reação dos capitalistas em razão de os fatos do 17 de outubro gerarem represálias por parte de várias empresas que suspenderam dirigentes e delegados sindicais. Os operários não se sentiam representados pelos partidos tradicionais que se haviam unido em uma frente única, a União Democrática, notabilizada por sua política antioperária. Daí a necessidade de organizar um partido político que concentrasse essa grande força massiva, que só esperava encontrar seu “leito natural” (REYES, 1987, p. 14).

Em 15 de novembro, foi aprovada a ata dos estatutos do novo partido pelo congresso partidário presidido por Luis Gay, com a seguinte declaração: “O novo partido é órgão político dos trabalhadores que propicia a candidatura do Coronel Juan Domingo Perón para a futura presidência da República" (REYES, 1987, p. 14). Em 1ํ de dezembro, Perón foi indicado como candidato oficial do laborismo para disputar o cargo político máximo da Nação. 
Pont (1984) afirma que o Partido Laborista foi uma organização política dos trabalhadores realmente autônoma e que o peronismo constituiu um Estado afinado com o movimento operário, mas com a firme intenção de intervir permanentemente no comportamento político do mesmo. A opção pela autonomia política do movimento sindical argentino surgiu da necessidade de protagonizar uma ação política que nenhuma outra política assumiu como objetivo:

[...] é assim que a gravitação crescente do movimento sindical, junto com a crise dos partidos políticos tradicionais e a oposição organizada contra a política social desenvolvida, fizeram que a classe operária organizada compreendesse a necessidade de converter-se em eixo de um nucleamento político nacional para a defesa de seus interesses de classe [...] Fundamentado em uma ampla base sindical, defendia o respeito em forma absoluta da autonomia e independência do movimento gremial. Elevava a classe operária ao plano político, em cujo terreno velaria pelas reivindicações gremiais, mas sem superditar a organização gremial à política, posto que se apoiavam e complementavam mutuamente [...] (PONT, 1984, p. 38-39, tradução nossa).

Nessa perspectiva, o movimento gremial poderia aderir ao Partido Laborista se fosse a vontade da maioria dos sindicatos, mas o partido desempenharia sua função política e ao sindicato caberia a função gremial. A criação de um partido dos trabalhadores foi uma decisão tomada conscientemente em nome da defesa da manutenção da política social desenvolvida pela Secretaria do Trabalho e Provisão Social dirigida por Perón, e um meio oficial e legítimo de participar no encaminhamento das soluções dos problemas nacionais.

Em resposta a Joseph F. McEvoy, diretor de notícias de La Prensa Associada, afiliada ao The Associate Press, em 10 de maio de 1946, sobre a interferência de Perón na criação do Partido Laborista, Luis Gay afirmou: "A ação do Coronel Perón é que apressou e facilitou a criação do Partido Laborista, surgido como uma necessidade histórica em momentos de intensa e dramática atividade revolucionária" (PONT, 1984, p. 56, tradução nossa). No entanto, da mesma forma que Perón apressou e facilitou a criação do Partido Laborista, sua dissolução, logo após as eleições de 1946, significou o primeiro passo para o fim da autonomia política do movimento operário argentino.

Com o retorno de Perón ao poder, foi iniciada sua campanha presidencial. Perón foi apoiado pelo Partido Laborista, composto pela maioria dos líderes da CGT1, de um setor dissidente do Partido União Cívica Radical do Povo, chamado Junta Renovadora, do Partido Patriótico, constituído por antigos conservadores e nacionalistas, e outras agremiações 
políticas menores. A fórmula Perón/Quijano venceu as eleições de 24 de fevereiro de 1946, apesar da forte oposição da União Democrática, frente política que reunia a UCR, o PDP, o PS, o PC e contava ainda com um hesitante apoio conservador.

Até o advento de Perón, a classe operária organizada não contava com uma estrutura orgânica que respaldasse as suas reivindicações. Essa afirmativa tem que ser entendida no contexto político-econômico de 1943. O PC e o PS não tiveram uma atuação política que preenchesse essa nova realidade:

[...] este vazio de representatividade política foi coberto pelo peronismo, que ofereceu as condições necessárias para que o movimento operário tivesse a oportunidade de alcançar essas metas, através de sua integração em um partido político próprio, o Partido Laborista [...] (PONT, 1984, p. 48, tradução nossa).

O retrocesso da democracia nas instituições políticas argentinas durante a década de 30 ajuda a explicar o porquê do êxito do peronismo. Da Secretaria do Trabalho, Perón manejou a classe trabalhadora, por meio de um sistema no qual os sindicatos tinham que ser reconhecidos pelo Estado. No contexto da política de Perón, é possível indagar qual foi o argumento dado às elites para justificar a política de massas que na década de 1920, apenas ensaiada já causara tantas reações da direita conservadora. Waisman (1987) afirma que Perón justificou suas políticas como única forma de defesa frente ao perigo eminente, o comunismo. O Estado corporativo e a industrialização seriam o antídoto para a ameaça da esquerda comunista.

Waisman (1987) analisa o discurso de Perón, enfocando o público receptor e suas reações. Enquanto os trabalhadores absorviam as vantagens da justiça social, os capitalistas estariam protegidos dos comunistas. É notável que Perón, anticomunista e anticapitalista, era radical quanto ao primeiro, mas considerava a possibilidade de outro tipo de capitalismo, o "humano", compatível com a justiça social para a classe trabalhadora. Nessa ordem, Perón salvaria o capitalismo pela humanização, e ainda evitaria uma revolução comunista (WAISMAN, 1987, p. 176). O antídoto a ser aplicado na sociedade parecia perfeito. O resultado foi um movimento trabalhista de massa sem precedentes no país, que serviu como o pilar fundamental de sustentação de Perón no poder. Desta forma, o governo de Perón, considerado populista por vários historiadores, teve como principal protagonista, em sua origem, os militares, mas foram os sindicatos que deram ao tipo de Estado que se instalou um 
formato peculiar, tornando a Argentina internacionalmente conhecida como "República Sindicalista" ${ }^{10}$

\section{Conclusão}

O peronismo foi um fenômeno cuja origem na história pode ser datada com precisão. Foi exatamente no início da década de 1940 que o nome de Perón começou a circular nos meios políticos da Argentina, alcançando seu auge no golpe de junho de 1943. Pouco tempo depois do golpe, Perón já era visto e considerado como o "homem forte" do novo regime. Em 1940, Perón havia voltado à Argentina, depois de passar um período na Itália, onde, supostamente, tornou-se simpatizante dos métodos totalitários nazifascistas. Foi enviado para a base militar da Província Andina de Mendonza, tornando-se um dos founding fathers do GOU (Grupo de Oficiales Unidos). O GOU foi formado por um grupo de jovens oficiais que tinha como proposta dar uma orientação política para o exército. Em 4 de junho de 1943, um golpe de Estado, organizado e dirigido pelo grupo, deu fim à Década Infame iniciada em 1930.

As condições políticas em que se deu o golpe de junho de 1943 foram muito distintas daquelas de quando se deu o golpe de militar de 1930. A oposição a Yrigoyen em 1930 era clara o suficiente para que o golpe não se apresentasse como uma surpresa para a sociedade. Também não havia a mesma desconfiança pública que previsse um golpe político-militar como em 1930. Ainda que muitos políticos soubessem do movimento, a expectativa de um levante militar era para setembro, quando estavam previstas as eleições presidenciais. O golpe foi realizado por um grupo de oficiais divididos, mas com o objetivo comum e primordial de "colocar a Nação em ordem". Foi pela ausência de harmonia e sintonia entre as personalidades golpistas e a incapacidade dos mesmos de enfrentar as decisões políticas fundamentais que Perón se destacou e pavimentou o que seria a "peronização da Argentina". A ordenação da sociedade em desordem foi a palavra de ordem do peronismo.

O golpe deu fim ao regime conservador, quando assumiu o poder o General Rawson, substituído dois dias depois pelo General Pedro Pablo Ramirez, ex-ministro de guerra do deposto Presidente Castillo. Para o cargo de Ministro de Guerra foi designado o General Farrell, chefe de Perón, que o nomeou subsecretário do ministério. Ainda que submetido ao General Farrell, Perón buscou cada vez mais o apoio dos jovens oficiais, incentivando-os a

\footnotetext{
${ }^{10}$ Sobre o populismo ver: CHAUÍ (1994), FERREIRA (2001, 2002), GOMES (2002), SANTOS (1993).
} 
afiliar-se ao GOU como uma maneira de demonstrar seu apoio ao governo militar. A par disso a política oficial favorecia ao GOU, criando uma base forte de poder através dos vários regimentos da Capital Federal e do Campo de Mayo, que foram confiados a membros da Loja.

A atitude catalisadora de Perón criou um grande mal-estar entre os chefes que haviam participado da derrocada de Castillo, inclusive pressionando o General Farrell a impedir as investidas de Perón. Este, respaldado pelo Ministro da Guerra, atribuía à GOU os acontecimentos do 4 de junho e o "verdadeiro espírito da revolução" (POTASH, 1971, p. 304).

Entende-se que o processo de peronização teve como grande articulador o próprio Perón, que se valeu de seus cargos políticos para construir o que chamou de "Nova Argentina". Sua figura transformou o cenário político do país dividindo-o em peronistas e antiperonistas. Enquanto os grupos políticos tradicionais e as elites sociais e econômicas o enfrentavam contra a política social e trabalhista, Perón era defendido pelos trabalhadores, que reconheciam o caráter social de seu plano de reformas, em que pese a repressão e as medidas autoritárias que já eram visíveis antes de eleito presidente da República.

Concorda-se com a tese de Murmis e Portantiero (1971), que afirmaram a presença dos antigos sindicatos no suporte à política de Perón, apoiado por uma grande massa de trabalhadores, que buscava ganhar espaço dentro do campo sindical. O fato de grande parte dos sindicatos argentinos, especialmente os antigos, serem de orientação de esquerda não impediu que, aos poucos, se submetessem à política peronista e se aproveitassem dos benefícios advindos da Secretaria do Trabalho e Bem-Estar Social.

Foi no contexto de violentos enfrentamentos com a polícia, de um lado, e com algumas lideranças sindicais mais radicais, de outro, que a identidade entre a massa trabalhadora e Perón foi formulada e afirmada. A peronização do país teve como base uma política promovida pelo Estado, referendada em 1945 pela mobilização dos trabalhadores nas ruas, no histórico 17 de outubro.

No entanto, o peronismo e a peronização da Argentina não foram uma obra exclusiva de Perón ou, melhor dizendo, de um só homem. Foi uma estratégia política notável construída por agentes sociais, aliados a uma grande estrutura burocrática, com quadros encarregados de elaborar políticas peronistas: deputados dispostos a sancionar leis peronistas, funcionários 
públicos envolvidos com a implementação do peronismo, intelectuais peronistas e uma vasta rede de propaganda para publicizar e tornar viável a legitimação da nova ordem.

Líder inquestionável dos trabalhadores argentinos, a ideologia da ordem e da nação em paz foi a bandeira sob a qual a comunidade foi organizada. Conquistar a massa foi uma tarefa simples perante a tarefa futura de mantê-la conquistada. Como afirmou Torre (1988), Perón só teria sua liderança renovada caso se mantivesse em constante negociação com as massas, para referendar sua autoridade sobre elas. Assim como na psicanálise a volta ao passado é uma permanente atualização de sentimentos, na política, as condições da origem de certos fenômenos, como foi o peronismo, tinham que ser revisitadas de tempos em tempos para manter o fôlego do regime.

\section{REFERÊNCIAS BIBLIOGRÁFICAS}

JORNAIS

Crítica, Buenos Aires, 17 de Octubre de 1945

La Nación, 1943 a 1945

La Prensa, Buenos Aires, 1945 a 1946

Orientación - Órgano Oficial del Partido Comunista, Buenos Aires, 1945 a 1946

REFERÊNCIAS

ARAÚJO, Enrique Diaz. El GOU en la Revolución de 1943. Mendonza: Universidad Nacional de Cuyo, 1970.

ARENDT, Hannah. Da revolução. São Paulo: Ática, 1988.

BAILY, Samuel. Movimiento obrero, nacionalismo y política en la Argentina. Buenos Aires: Paidós, 1984.

BERGQUIST, Charles. Los trabajadores en la historia latino-americana. Colombia: Siglo XXI, 1990.

CHAUÍ, Marilena. Teocracia dos dominantes e messianismo dos dominados. In: DAGNINO, Evelina (Org.). Anos 90: política e sociedade no Brasil. São Paulo: Brasiliense, 1994.

CíRIA, Alberto. Partidos políticos y poder en la Argentina moderna (1930-1946). Buenos Aires: Jorge Alvarez, 1964.

CODOVILLA, Victorio. Esbozo de la historia del Partido Comunista de la Argentina - 1918-6 de enero1948. Buenos Aires: Editorial Anteo, 1947.

DEUTSCH, Sandra McGee; DOLKART, Ronald H. (Ed.). The Argentine-Right: its history and intellectual origins, 1910 to the present. Wilmington, DE: SR Books, 1993.

FERREIRA, Jorge (Org.). O populismo e sua história. Rio de Janeiro: Civilização Brasileira, 2001. 
FERREIRA, Jorge. Queremismo, trabalhadores e cultura política. Soberania popular e aprendizado democrático. Revista Varia Historia, v. 28, p. 69-84, 2002.

FOUCAULT, Michel. Em defesa da sociedade. São Paulo: Martins Fontes, 1999.

FOUCAULT, Michel. Microfísica do poder. Rio de Janeiro: Graal, 2000.

GERASSI, Marysa Navarro. Los nacionalistas. Buenos Aires: Ed. Jorge Alvarez, 1968.

GODIO, Julio. Historia del movimiento obrero argentino. Buenos Aires: Ediciones Corregedor, 2000.

GOMES, Angela de Castro. Reflexões em torno do populismo e trabalhismo. Revista Varia Historia, v. 28, p. 55-68, 2002.

ISCARO, Rubens. Orientación - Órgano Oficial del Partido Comunista. Buenos Aires, Octubre. 1945/Julio. 1946; 18 de Septiembre de 1946.

KAPLAN, Marcos. Cinqüenta anos de História Argentina (1925-1975): o labirinto da frustração. In: CASANOVA, Pablo González. América Latina - história de meio século. Brasília: Ed. UnB, 1988.

MATSUSHITA, Hiroschi. Movimiento obrero argentino 1930-1945: sus proyecciones en los orígenes del peronismo. Buenos Aires: Ediciones Siglo Veinte, 1983.

MURMIS, Miguel; PORTANTIERO, Juan Carlos. Estudios sobre los orígenes del peronismo. Buenos Aires: Siglo XXI, 1971.

PANEBIANCO, Angelo. Political parties. New York: Cambridge University Press, 1988.

PERÓN, Juan Domingo. Mensagem transmitida pelo rádio em 2 de dezembro de 1943. In: El pueblo quiere saber de que se trata. Buenos Aires, 1944.

PLOTKIN, Mariano. Rituales políticos, imágenes y carisma: la celebración del 17 de octubre y el imaginario peronista 1945-1951. In: TORRE, Juan Carlos (Comp.). El 17 de octubre de 1945. Buenos Aires: Ariel, 1995.

PONT, Elena Susana. Partido Laborista: estado y sindicatos. Buenos Aires: Biblioteca Política Argentina, 1984.

POTASH, Robert A. El ejército y la política en la Argentina 1928-1945. De Yrigoyen a Perón. Buenos Aires: Editorial Sudamericana, 1971.

POTASH, Robert A. Perón y el GOU: los documentos de una logia secreta. Buenos Aires: Ed. Sudamericana, 1984.

REAL, Juan José. 30 años de história argentina. Buenos Aires: Actualidad, 1962.

REYES, Cipriano. La farsa del peronismo. Buenos Aires: Sudamericana, 1987.

ROUQUIÉ, Alain. Poder militar y sociedad política en la Argentina I - hasta 1943. Buenos Aires: Emecé Ed., 1978.

SANTOS, Wanderley Guilherme dos. A gênese da ordem. In: SANTOS, Wanderley Guilherme dos. Razões da desordem. Rio de Janeiro: Rocco, 1993. 
SIGAL, Silvia; VERÓN, Eliseo. Perón o muerte: los fundamentos discursivos del fenómeno peronista Buenos Aires: Editorial Legasa, 1986.

TORRE, Juan Carlos. La formación del sindicalismo peronista. Buenos Aires: Legasa, 1988.

TORRE, Juan Carlos (Comp.). El 17 de octubre de 1945. Buenos Aires: Arial, 1995.

TRONCOSO, Oscar. Los nacionalistas argentinos. Buenos Aires: Editorial S.A.G.A., 1957.

WAISMAN, Carlos H. Reversal of development in Argentina: postwar counterrevolutionary policies and their structural consequences. Princeton: Princeton University Press, 1987.

YRIGOYEN, Hipólito. Pueblo y gobierno, y mensajes. Buenos Aires: Raigal, 1953.

ZAMOR, Jean Claude Garcia. Public administration and social changes in Argentina (1943/1955). Rio de Janeiro: GB, 1968. 